\title{
PELATIHAN ENRICHMENT DAPHNIA UNTUK MENINGKATKAN KECERAHAN WARNA IKAN CUPANG (Betta sp.)
}

\author{
Andika Putriningtias'), Siti Komariyah"1), Silvia Anzitha') \\ 1)Program Studi Akuakultur, Fakultas Pertanian, Universitas Samudra, Langsa, Aceh, Indonesia \\ 2)Program Studi Agribisnis, Fakultas Pertanian, Universitas Samudra, Langsa, Aceh, Indonesia \\ Corresponding author : Siti Komariyah \\ E-mail: sitikomariyah_adam@yahoo.com
}

Diterima 06 Oktober 2021, Disetujui 26 November 2021

\begin{abstract}
ABSTRAK
Permasalahan yang dihadapi mitra adalah rendahnya kualitas warna ikan cupang yang mitra peroleh dari agen, sehingga harga jual ikan cupang juga rendah. Setelah mengetahui permasalahan mitra, tim menawarkan solusi yaitu pelatihan enrichment Daphnia untuk memanipulasi pigmen warna ikan cupang. Tujuan dari pengabdian ini adalah memberikan pelatihan kepada pemuda dan para penggiat ikan cupang di Gampong Teungoh, Kota Langsa tentang enrichment Daphnia sebagai pakan ikan cupang yang dapat meninngkatkan kecerahan warna ikan cupang. Metode yang digunakan adalah sosialisasi dan penjaringan mitra, pemberian materi tentang faktor-faktor yang mempengaruhi kecerahan warna ikan cupang serta teknik enrichment pakan ikan cupang dan pelatihan teknik enrichment pakan ikan cupang. Mitra yang mengikuti kegiatan ini adalah pemuda gampong dan penggiat ikan cupang di Gampong Teungoh yang berjumlah 25 orang. Evaluasi keberhasilan pelatihan dihitung berdasarkan kepahaman para peserta terhadap materi pelatihan. Hasil yang dicapai dari pelatihan ini yaitu adanya peningkatan ketrampilan para pemuda dan penggiat ikan cupang dalam meningkatkan warna ikan cupang dan juga adanya peningkatan harga jual ikan yang telah diberikan pakan Daphnia yang telah di enrichment.
\end{abstract}

Kata kunci: astaxhantin; daphnia; ikan cupang; kecerahan warna; pakan alami.

\begin{abstract}
The problem faced by partners is the low quality of betta fish colors that partners get from agents, so the selling price of betta fish is also low. After knowing the partners' problems, the team offered a solution, namely Daphnia enrichment training to manipulate betta fish color pigments. The purpose of this service is to provide training to youth and betta fish activists in Gampong Teungoh, Langsa City on the enrichment of Daphnia as betta fish food that can increase the brightness of the color of betta fish. The methods used were socialization and partner networking, providing material about the factors that affect the color brightness of betta fish and betta fish feed enrichment techniques and training on betta fish feed enrichment techniques. Partners who participated in this activity were village youth and betta fish activists in Teungoh Village, totaling 25 people. The evaluation of the success of the training is calculated based on the participants' understanding of the training material. The results achieved from this training are an increase in the skills of young people and betta fish activists in increasing the color of betta fish and also an increase in the selling price of fish that have been given enrichment Daphnia feed.
\end{abstract}

Keywords: astaxhantin; daphnia; betta fish; color brightness; natural food

\section{PENDAHULUAN}

Ikan hias merupakan satu komoditas ekonomi non migas yang potensial. Peminat ikan hias terus meningkat baik di dalam maupun luar negeri, hal ini mendorong perkembangan budidaya ikan hias di Indonesia. Salah satu jenis ikan hias yang mempunyai nilai ekonomis tinggi adalah ikan cupang (Betta sp.) (Ostrow, 1989). Ikan cupang merupakan salah satu ikan hias yang mudah dipelihara, budidaya ikan cupang tidak perlu tempat yang luas dan modal yang besar, bisa dilakukan sebagai usaha rumahan (Destrana \& Rafiudin, 2019).
Ikan cupang yang berkelamin jantan mempunyai warna yang lebih menarik dengan siripnya yang indah dan memiliki nilai komersial lebih tinggi daripada betina. Ikan cupang jantan sangat agresif dan memiliki kebiasaan saling menyerang apabila ditempatkan dalam satu wadah sehingga digunakan sebagai ikan laga (fighting fish) (Ostrow, 1989). Ikan cupang (Betta sp.) merupakan salah satu ikan hias yang banyak digemari masyarakat, baik dari kalangan dewasa maupun anak-anak. Bahkan di tengah pandemic covid 19 ikan hias ini menjadi primadona bagi para pecinta ikan hias 
untuk menghilangkan kebosanan dan berwirausaha. Kewirausahaan bukan hanya memfokuskan pada seberapa besar input yang mendukung bisnis, tetapi lebih pada bagaimana untuk mendayagunakan potensi apapun yang tersedia untuk mencapai kontribusi output bagi kesejahteraan ekonomi (Rahmi et al., 2020). Sehingga ikan hias ini menjadi lahan bisnis ditengah menurunnya perekonomian. Salah satu Gampong di Kota Langsa yang masyarakatnya memanfaatkan peluang bisnis ikan cupang ini adalah Gampong Teungoh, Kota Langsa.

Para penggiat dan penjual ikan cupang di Gampong Teungoh tergabung dengan sebuah komunitas di Kota Langsa bernama "Cupang Elok". Berdasarkan hasil wawancara dengan salah satu anggota komunitas tersebut yaitu bernama bang Mus, bahwa saat ini para penjual ikan cupang mendapatkan ikan cupang dari pulau Jawa, mereka belum mampu membudidayakan ikan cupang secara mandiri. Selain itu, warna ikan cupang yang mereka peroleh juga kurang cerah sehingga harga jualnya reatif murah, yaitu hanya Rp. 10.000,per ekor.

Harga jual ikan cupang sangat bervariasi tergantung dari keindahan warna dan ekornya. Semakin menarik warna dan ekor ikan cupang harganya akan semakin tinggi, bahkan bisa mencapai Rp. 500.000,-/ekor. Upaya untuk meningkatkan kecerahan warna ikan dengan menambahkan karotenoid yang merupakan komponen pembentuk warna merah dan kuning (Indarti et al., 2012). Kecerahan warna ikan cupang dapat ditingkatkan dengan beberapa cara, salah satunya dengan teknik manipulasi pigmen untuk mendapatkan warna indah dan cerah pada ikan cupang, yaitu dengan cara memperkaya kandungan sel pigmen dalam tubuh ikan melalui pemberian pakan yang mengandung karetenoid, astaxanthin (CarophyllC red). Penambahan pigmen astaxanthin ke dalam pakan ikan cupang dapat dilakukan dengan di-enrichment pada Daphnia yang merupakan pakan alami utama ikan cupang. Penelitian sebelumnya juga telah dilakukan oleh Melati et al., (2017)

Agar para penjual ikan cupang mendapat keuntungan yang besar, maka para penjual harus mampu menciptakan ikan cupang dengan warna yang menarik para pecinta ikan cupang. Berdasarkan permasalahan di atas, alternatif yang dapat diupayakan adalah dengan memberikan pelatihan teknik enrichment (pengkayaan) Daphnia sebagai pakan ikan cupang. Daphnia spp. merupakan sumber pakan alami yang potensial untuk dikembangkan bagi larva ikan (Mubarak et al., 2009). Diharapkan setelah pelatihan ini, para penjual ikan cupang di Gampong Teungoh dapat memproduksi ikan cupang dengan warna yang menarik sehingga meningkatkan harga jual ikan cupang dan keuntungan yang diperoleh juga meningkat.

\section{METODE \\ Prosedur kerja untuk mendukung realisasi metode yang ditawarkan}

Untuk mendukung realisasi metode yang ditawarkan, berikut ini merupakan prosedur kerja yang menunjukkan gambaran hubungan kerja dengan mitra yang sudah ditetapkan:

1. Sosialisasi dan penjaringan mitra

2. Pemberian materi tentang faktor-faktor yang mempengaruhi kecerahan warna ikan cupang serta teknik enrichment pakan ikan cupang.

3. Pelatihan teknik enrichment pakan ikan cupang.

\section{Metode Pelaksanaan Kegiatan Pengabdian Kepada Masyarakat}

Adapun metode pelaksanaan kegiatan pengabdian ini menggunakan metode pendekatan secara langsung dan ceramah. Adapun tahapan yang dilakukan dalam pelaksanaan kegiatan ini meliputi:

\section{Tahap Persiapan}

Sosialisasi dilakukan di daerah tujuan pelaksanaan program pengabdian kepada masyarakat yang melibatkan masyarakat setempat. Target masyarakat yang dijadikan Mitra adalah komunitas penggiat ikan cupang khususnya penjual ikan cupang di Gampong Teungoh Kecamatan Langsa Kota. Pada kegiatan program sosialisasi semua komunitas penggiat ikan cupang khususnya penjual ikan cupang di Gampong Teungoh ikut terlibat sebagia audien.

Dalam tahapan persiapan ini, tim pelaksana kegiatan pengabdian kepada masyarakat melakukan diskusi dengan Ketua komunitas Penggiat Ikan Cupang dengan tujuan untuk:

1) Memberikan informasi tentang tujuan dan maksud program pengabdian kepada masyarakat tersebut dilaksanakan.

2) Melakukan pendataan anggota komunitas penggiat ikan cupang terutama penjual ikan cupang yang ada di Gampong Teungoh dan sumber ikan cupang dijual.

3) Melakukan diskusi tentang kedala yang dihadapi mitra dalam melakukan pemeliharaan ikan cupang khususnya terkait kualitas warna ikan cupang.

4) Mendiskusikan faktor-faktor yang mempengaruhi harga jual ikan cupang di pasaran dan peminat ikan cupang. 
5) Mendiskusikan jadwal pelaksanaan program kegiatan pengabdian kepada masyarakat ini.

\section{Ceramah}

Tim menyiapkan materi dan bahan peraga yang akan disampaikan pada peserta. Materi yang akan disajikan adalah sebagai berikut :

1. Memberikan informasi faktor-faktor yang mempengaruhi kualitas warna ikan cupang.

2. Memberikan pigmen yang dapat ditambahkan dalam pakan untuk meningkatkan kualitas warna ikan cupang.
3. Memberikan informasi teknik enricmen pakan untuk meningkatkan kualitas warna ikan cupang.

4. Memberikan informasi alat dan bahan dalam kegiatan enrichment pakan ikan cupang.

\section{Pelatihan Enrichmen Pakan Ikan Cupang}

Tim menyiapkan peralatan dan bahan yang dibutuhkan. Alat dan bahan yang digunakan dapat dilihat pada Tabel 2.

Tabel 2. Alat dan bahan enrichment Dapnia sebagai pakan ikan cupang

\begin{tabular}{llll}
\hline No & Alat dan Bahan & Jumlah & Kegunaan \\
\hline 1 & Akuarium/toples & 2 & Wadah ikan cupang dan Daphnia \\
2 & Aerator set & 2 & Pensuplay oksigen \\
3 & Heater & 2 & Pengatur suhu air \\
4 & Timbangan & 1 & Menimbang dosis Astaxanthin \\
5 & Ikan cupang & 10 ekor & Biota uji \\
& $\begin{array}{l}\text { berjenis kelamin } \\
\text { jatan }\end{array}$ & \\
6 & Astaxanthin & $100 \mathrm{~g}$ & Bahan uji \\
7 & Daphnia sp. & 200 ekor & Pakan ikan cupang \\
8 & Ragi & $250 \mathrm{~g}$ & Pakan Daphnia \\
\hline
\end{tabular}

Ikan cupang berwarna merah diperoleh dari penjual ikan cupang di Gampong Teungoh, Kota Langsa, sementara Daphnia diperoleh dari BBI Lukup Badak, Aceh Tengah. Ikan cupang yang akan ditingkatkan kecerahan warnanya adalah ikan yang sudah memasuki fase juvenile. Dosis astaxanthin yang diberikan ke Dapnia adalah $0,5 \mathrm{mg} / \mathrm{L}$ air, dosis ini merupakan dosis yang efektif meningkatkan kecerahan warna ikan cupang (Prasetyo et al., 2020). Lama perendaman Daphnia ke dalam larutan astaxanthin yaitu 15 menit. Setelah 15 menit, Daphnia yang sudah diperkaya diberikan ke ikan. Untuk melihat hasil peningkatan warna ikan cupang, daphnia yang sudah diperkaya astaxanthin, diberikan ke ikan selama kurang lebih 3 minggu.

\section{HASIL DAN PEMBAHASAN}

Sosialisasi dan pelatihan enrichment (pengkayaan) Daphnia sebagai pakan untuk meningkatkan kecerahan warna ikan cupang (Betta sp.) di Gampong Teungoh, Kota Langsa dilaksanakan pada hari minggu, tanggal 15 Agustus 2021. Sasaran kegiatan ini adalah para penjual ikan cupang di sekitar Gampong Teungoh, namun yang hadir pada kegiatan pengabdian ini tidak hanya penjual ikan cupang, tetapi juga dihadiri para pemuda Gampong Teungoh yang tertarik terhadap ikan cupang. Perangkat desa dan para peserta yang hadir sangat antusias dalam kegiatan ini.
Hal ini terlihat dari banyaknya pertanyaan dari para peserta.

Sebelum kegiatan dilakukan, Tim pengabdian menerapkan protokol kesehatan selama kegiatan berlangsung. Adapaun langkah yang dilakukan Tim adalah menyediakan masker dan handanitizer sebelum pintu masuk ruangan dan membagikan masker kepada peserta yang tidak membawa masker (Gambar 1). Peraturan dalam penggunaan masker dan himbauan untuk mencuci tangan masih sangat ada yang mengabaikan untuk mengikuti peraturan tersebut. Hal ini dikarenakan juga kurangnya pengetahuan yang dimiliki masyarakat dan langkahnya masker dikalangan masyarakat. Oleh sebab itu, perlu adanya ketersediaan fasilitas cuci tangan di rumah maupun di tempat umum serta pengunaan masker yang baik dan benar di tempat umum (Fristiohady et al., 2021). 


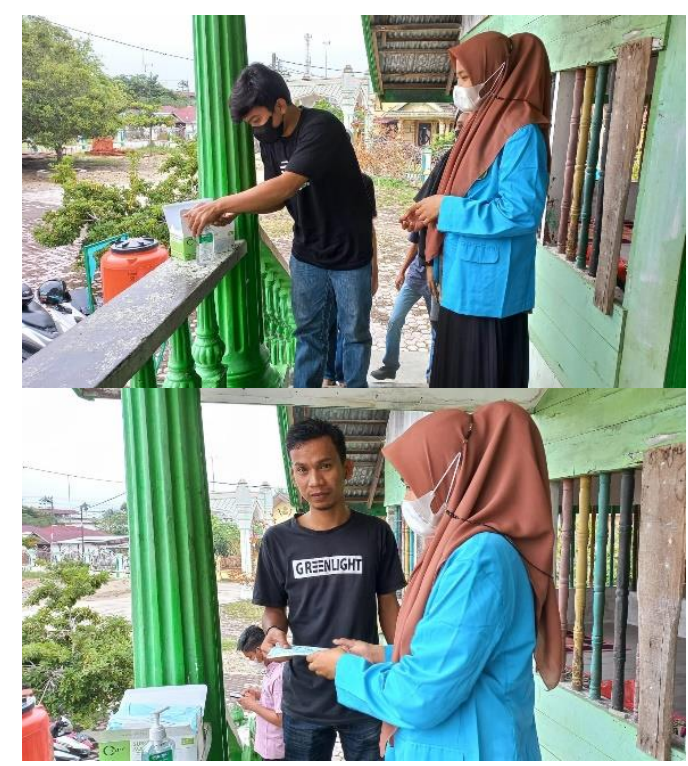

Gambar 1. Penerapan protokol kesehatan sebeum kegiatan berlangsung

Sebelum sosialisasi dan pelatihan dimulai, terlebih dahulu dibuka dengan kata sambutan oleh perwakilan dari Bapak Zainal Abidinn (Geucik Gampong Teungoh), yaitu Bapak Rizky Armada (Kaur Perencanaan Pemerintah Gampong Teungoh) (Gambar 2). Dalam sambutannya Bapak Rizky menyampaikan bahwa kegiatan ini bernilai sangat positif dalam meningkatkan SDM Gampong Teungoh, selain itu Beliau juga menyampaikan kegiatan ini merupakan salah satu upaya dalam mempertahankan perekonomian yang sedang merosot di masa pandemi covid 19.

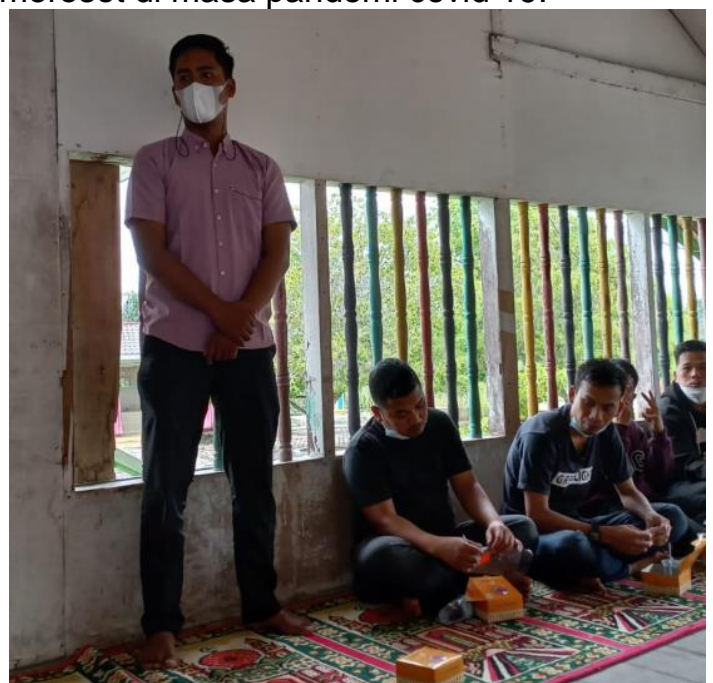

Gambar 2. Sambutan oleh Perwakilan Geucik Gampong Teungoh.

Setelah kata sambutan kemudian dilanjutkan penyampaian materi oleh lbu Siti Komariyah, S.I.K., M.Si. yang merupakan anggota Tim pengabdin dan juga dosen Fakultas Pertanian Unsam yang membidangi nutrisi dan pakan ikan (Gambar 3). Setelah penyampaian materi, dilanjutnya sesi tanya jawab. Dari sesi tanya jawab atau diskusi, diperoleh informasi sebagai berikut:

1) Baik penjual atau pembudidaya ikan cupang maupun peserta lainnya yang hadir belum mengenal apa itu astaxanthin, namun mereka sudah mengetahui bahan lain yang digunakan untuk meningkatkan kecerahan ikan cupang seperti bubuk sprirulina dan daun ketapang.

2) Penjual ikan cupang sudah mengetahui cara meningkatkan kecerahan ikan cupang, namun teknik yang digunakan sedikit berbeda dengan yang Tim pengabdian sampaikan. Sehingga dalam hal ini terdapat pertukaran ilmu dan informasi yang sangat bermanfaat bagi kedua belah pihak dalam meningkatkan kualitas ikan cupang. Sementara peserta dari pemuda Gampong banyak yang masih awam baik terkait budidaya ikan cupang maupun enrichment/pengkayaan pakan untuk meningkatkan kecerahan warna ikan hias.

3) Diakhir diskusi, peserta menyayangkan mengapa kegiatan yang sangat bermanfaat seperti ini baru dilakukan sekarang. Peserta berharap, Tim bersedia menyelenggarakan kegiatan sejenisnya di desa mereka.

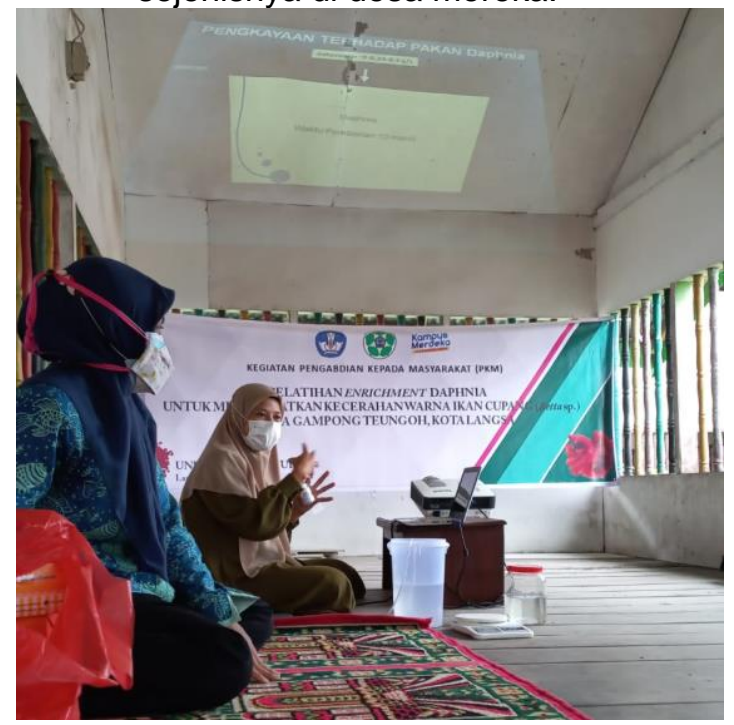

Gambar 3. Penyampaian materi oleh tim Pengabdian kepada Masyarakat

Setelah penyampaian materi, dilanjutkan dengan tim menjelaskan dan menunjukkan alat dan bahan yang digunakan dalam enrichment Daphnia (Gambar 4). Alat yang digunakan adalah timbangan untuk menimbang dosis astaxanthin, toples sebagai wadah kultur 
daphnia dan wadah ikan cupang, serta aerator sebagai pensuplai oksigen bagi Daphnia. Sedangkan bahan yang digunakan adalah ikan cupang, Daphnia dan astaxanthin. Kemudian tim mendemokan teknik atau prosedur kerja enrichment Daphnia (Gambar 5). Dosis asthaxanthin yang digunakan merujuk hasil penelitian (Prasetyo et al., 2020)

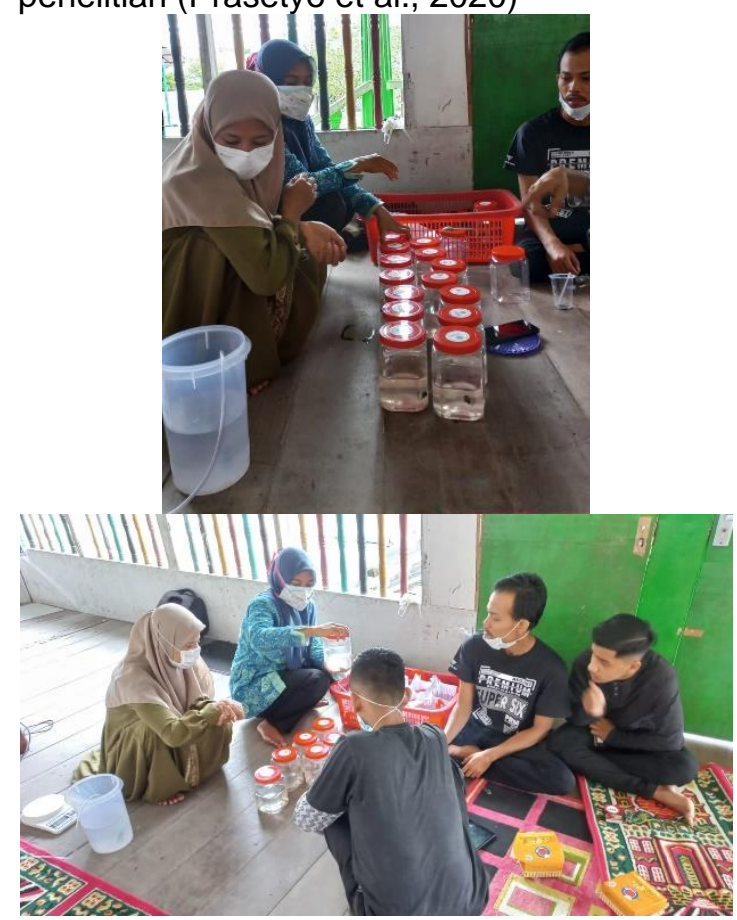

Gambar 5. Demo enrichment Daphnia.

Diakhir acara tim menyerahkan souvenir berupa 1 ekor ikan cupang kepada setiap peserta (Gambar 6) dan foto bersama (Gambar 7). Tim pengandapdian berharap peserta dapat mengaplikasikan apa yang sudah peserta dapat dalam kegiatan pengabdian ini. Sementara produk dari kegiatan ini adalah pakan ikan cupang yaitu Daphnia yang sudah dienrichmen. Adapaun produk tersebut dapat dilihat pada Gambar 7.

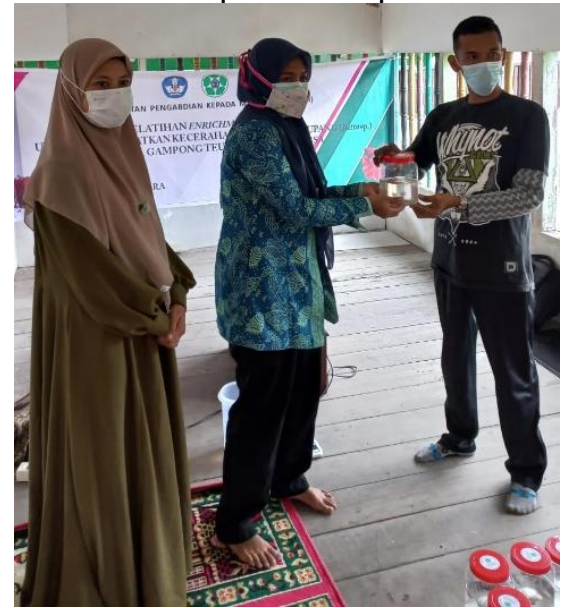

Gambar 6. Penyerahan souvenir ikan cupang kepada peserta pengandian kepada masyarakat.

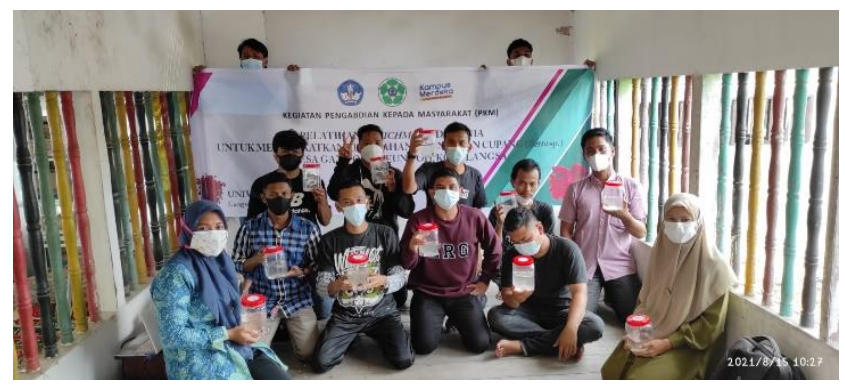

Gambar 7. Foto bersama dengan para peserta

\section{SIMPULAN DAN SARAN}

Kesimpulan dari kegiatan Pengabdian kepada Masyarakay di Gampong Teungoh adalah adanya peningkatan pengetahuan masyarakat tentang enrichment Daphnia menggunakan astaxanthin sebagai pakan untuk meningkatkan kecerahan warna ikan cupang (Betta sp.) serta antuasias masyarakat untuk melakukan enrichment Daphnia menggunakan astaxanthin.

Masyarakat sangat antusias untuk melakukan enrichment Daphnia sebagai pakan ikan cupang, namun dari peserta yang berasal dari kalangan pemuda yang bukan sebagai penjual ikan cupang belum faham tentang teknik kultur Daphnia itu sendiri. Sehingga perlu dilakukan kegiatan sejenisnya tentang pelatihan kultur Daphnia di Gampong Teungoh.

\section{UCAPAN TERIMAKASIH}

Untuk menghindari kesalahan penulisan artikel, kami sarankan untuk langsung menggunakan dokumen ini sebagai master. Tinggal hapus isi petunjuk penulisan ini, namun harap save as dahulu sesuai dengan nama file yang diminta. Bila mengalami kesulitan, Redaksi akan membantu dan memperjelas. Wassalam dan semoga petunjuk ini berguna bagi para penulis.

\section{DAFTAR RUJUKAN}

Destrana, R., \& Rafiudin, M. D. (2019). Analisis dan perancangan e-bisnis dalam budidaya dan penjualan ikan cupang menggunakan metodelogi overview Jurnal Teknik Informatika (JIKA) Universitas Muhammadiyah Tan, 3(1), 51-58.

https://doi.org/http://dx.doi.org/10.31000/j ika.v3i1.2045

Indarti, S., Muhaemin, M., \& Hudaidah, S. (2012). MODIFIED TOCA COLOUR FINDER (M-TCF) DAN KROMATOFOR SEBAGAI PENDUGA TINGKAT KECERAHAN WARNA IKAN KOMET (Carasius auratus auratus) YANG DIBERI PAKAN DENGAN PROPORSI 
TEPUNG KEPALA UDANG (TKU) YANG

BERBEDA. E-Jurnal Rekayasa Dan

Teknologi Budidaya Perairan, I(1).

Melati, B., Rahayu, R., \& Finder, T. C. (2017). PENINGKATAN KUALITAS WARNA IKAN CUPANG (Betta splendens) Regan, 1910 MELALUI PAKAN YANG DIPERKAYA DENGAN TEPUNG UDANG REBON SEBAGAI SUMBER KAROTENOID. 236(2), 231-236.

Mubarak, A. S., Tias, D. T. R., \& Sulmartiwi, L. (2009). PEMBERIAN DOLOMIT PADA KULTUR DAPHNIA SPP. SISTEM DAILY FEEDING PADA POPULASI DAPHNIA SPP. DAN KESTABILAN KUALITAS AIR. DOLOMITE. Jurnal IImiah Perikanan Dan Kelautan, 1(1), 67-72.

Prasetyo, D., Handajani, H., Hermawan, D., Fuhaira., I., \& (Program Studi Akuakultur, Fakultas Pertanian-Peternakan, Universitas Muhammadiyah Malang, I. (2020). Pengaruh pengkayaan Daphnia $s p$. menggunakan astaxanthin terhadap kualitas warna merah ikan Cupang Halfmoon ( Betta splendens, Regan 1910 ) Effect of the enrichment of Daphnia $s p$. with astaxanthin on the red color quality. 4(1), 32-37.

Rahmi, V. A., Ismanto, H., Fathoni, M. Z., Kewirausahaan, S., Gresik, U. M., Studi, P., Industri, T., Teknik, F., \& Gresik, U. M. (2020). Inovatif Saat Pandemi Covid Pelatihan Kewirausahaan Khas Perempuan Berbahan Sampah " Kolaborasi BUMDes ." DINAMISIA: Jurnal Pengabdian Kepada Masyarakat, 4(3), 418-425. 